\title{
Using of Bangun-Bangun Leafs (Coleus Amboinicus, L) on Red Sugar Block to Upgrading Milk Production of Frisian Holstein
}

\author{
Nelzi Fati ${ }^{\# 1}$, Irzal Irda ${ }^{\# 2}$ and Debby Syukriani ${ }^{\# 3}$ \\ \# Agricultural Polytechnic State of Payakumbuh, West Sumatera, Indonesia \\ E-mail: ${ }^{1}$ Nelzifati@gmail.com; ${ }^{2}$ Irzalirda@yahoo.com; ${ }^{3}$ syukrianidebby@yahoo.co.id
}

\begin{abstract}
Science and technology for the Community Activities Program (IBM) granting wake leaf meal in urea red sugar block has been implemented in a herd prosperous green valley village Kampung Manggis, Western District of Padang Panjang, Municipality of Leopold. This activity aims to increase the milk production of dairy cows through the application of technology utilization wake leaf meal in urea red sugar block. The benefits of this activity is to assist farmers in improving milk production per day, so that milk production can increase the impact on increasing revenue. To achieve the goal of service to the community mentioned above, it has been conducted lectures, live demonstrations on the making lick candy made from leaf shapes. Six cows used as a demonstration, two dairy cows with urea red sugar block containing $2.5 \%$ leaf shapes, two dairy cows with urea red sugar block containing leaf shapes $5 \%$ and two cows with urea red sugar block containing leaves wake up 7.5\%. Wake up dried leaves with the help of sunlight and then made ready for use in the flour mixture forming urea red sugar block which serves as a feed supplement in dairy cattle. Evaluation activities indicate that the application of urea red sugar block starchy wake leaves $5 \%$ can increase the production of milk 2 liters / day / head (average increase 10\%). Of this service activities can be concluded that the use of leaf meal wake up in $5 \%$ urea red sugar block can increase milk production of dairy cows 2 liters / day / head compared with $2.5 \%, 7.5 \%$.
\end{abstract}

Keywords - Milk production, urea saka block, leaf shapes

\section{INTRODUCTION}

Milk as one of the farm products is a source of animal protein that is increasingly required to improve the quality of life. In an effort to meet the needs of the dairy to improve the population, and productivity production of dairy cows.

Dairy cow population in Indonesia is about 407.767 thousan. West Sumatra (West Sumatra) approximately 780 thousand heads, Padang Panjang 340 head of dairy cattle population [1]. Domestic milk production is still largely dependent on the dairy farm of around 110 thousand farmers with an average daily production of 1,185 tons of fresh milk sold to the Milk Processing Industry (IPS) through cooperatives (Sulistiyo, 2008), but it has not been able to meet the needs of domestic consumer demand due to increased consumption of milk is relatively fast compared with its production. West Sumatra provincial government, is now targeting dairy cow milk production of 2,200 liters per day or 803 thousand liters per year to meet the demand of PT. Cocomas, Bukit Tinggi Hospital and dairy school children through the Child Supplementary Feeding Program School. Data dairy cow milk production in West Sumatra year (2007) reaching each 1.052 .640 liters of milk production centers from the city of Padang Panjang, 422280 liters, Tanah Datar district as much as 171360 liters, 247,680 liters of Padang city, 50 city districts as many as 136170 liters , Agam regency, 53550 liters and as much as 21,420 liters of Bukittinggi. Judging from the data of milk production in dairy cattle milk production center, the area of Padang Panjang is an area that produces the most milk, this is due to the area of Padang Panjang is an area that is most suitable to maintain dairy cattle. It is powered from a suitable temperature for the maintenance of dairy cows is $15 \mathrm{oC} \mathrm{-}$ $210 \mathrm{C}$ which is usually located in the plateau area [2]. Padang Panjang is a small town in the region of West Sumatra province with an area of 2,300 hectares or about 0.05 percent of the province of West Sumatra. Padang Panjang geographically located between 1000200 and 1000 300 east longitude and 00270 south latitude and 0032 and is flanked by the districts and sub-districts Batipuh X Koto which are the two regions of the district of Tanah Datar. Padang Panjang is an area of undulating topography and is located in the plateau area is famous for its cool climate with an altitude between 650 to 850 meters above sea level and has a fairly high rainfall. With a carrying capacity of this area causes the area of Padang Panjang. Padang Panjang is the center of production of dairy cows. Existing dairy 
farmers in the municipality of Padang Panjang is generally lower middle class. Thus raising dairy cattle is a sideline business to supplement the family income. In general, management of dairy cattle by livestock farmers still done traditionally. As an illustration of dairy cattle business today is the establishment of dairy cattle most of the small businesses that are odd, with an average tenure 2-5 tails. Milk production ranged between 6-8 liters per cow per day, this is caused by several factors such as seed, feed, management of, and calving interval length (over 18 months). The quality of dairy products produced with low average bacterial content (TPC> 5,000,000) and Total Solid (TS +/- 11\%), fat content $2.91 \%$, and 7.69 SNF. This is because the milking equipment and equipment for the transportation of milk does not meet the technical requirements, the average stable conditions are relatively dirty, milking way less attention to sanitation and hygienic dairy products. The main result of the maintenance of milk production of dairy cows are. To increase milk production can not be separated from the forage available. Forage needs of dairy cows per head is $10 \%$ of total body weight. Wake Plant (Coleus amboinicus L.) is one of the many properties of medicinal plants. Plants wake comes from North Sumatra and then taken by new comers to the area of West Sumatra.

Wake Plant has long been recognized in the community as a menu Tapanuli vegetables daily to increase stamina and facilitate milk products in the mother giving birth. The leaves have a particular scent so-called aromatic plants and contain essential oils. According [3] This plant contains a variety of flavonoids, namely quercetin, apigenin, luteolin, salvigenin, genkwanin. Reference [4], states these plants contain iron and carotene are high, so that the consumption of this plant can improve the levels of iron, potassium, zinc, and magnesium in milk and increase the baby's weight.

In pigs flour wake usage can improve feed conversion rate of breast feeding mother and child increases body weight gain [5]. Based on the above we conducted giving candy lick containing leaf shapes to increase the milk production of dairy cows. This activity aims to provide knowledge and skills to farmers about the making of candy lick containing leaf shapes that can increase production dairy milk. The benefits of this activity is to assist farmers in improving milk production through the provision of a feed supplement containing leaf shapes.

\section{METHOD}

Provide lectures and guidance on the benefits of leaf shapes. Giving and teaches how to make candy lick containing leaf shapes. Giving and guidance built directly into the field. Evaluate the results achieved during the implementation and ongoing coaching.

\section{RESULT AND DISCUSSION}

\section{A. Milk production}

Based on the evaluation results obtained information of milk production as shown in Table 1 were used as a demonstration Cattle on 3-year-old cattle rancher who was in second lactation and is at peak production. Dairy cows are reared FH (Fries Holland) and Simental cows. In livestock raising lactating dairy cows, cows given feed is forage and concentrate consisting of $1 \mathrm{~kg}$ of oil cake, corn $1 \mathrm{~kg}, 1 \mathrm{~kg}$ potato flour, mineral 50 grams, 50 grams pensi flour, bran and to pulp out $3 \mathrm{~kg}$. Giving concentrates in dairy cows $3 \mathrm{~kg}$, $6 \mathrm{~kg}$ of to pulp out and grass giving $30 \mathrm{~kg}$ each time, while granting performed twice, in the morning and afternoon. The technology applied here is the provision of a feed supplement in the form of blocks containing urea red sugar wake leaves twice a day. The percentage of leaf meal in the wake of the lick candy is $2.5 \%(\mathrm{~A}), 5 \%(\mathrm{~B})$ and $7.5 \%(\mathrm{C})$.

Based on the evaluation results of the application of science and technology activities that have been carried out on groups of prosperous green valleys found that administration of urea red sugar block containing leaves wake up 5\% which is a feed supplement for cattle can increase milk production by $10 \%$ of milk production is not given urea red sugar blocks with sufficient feed such as concentrates are given in the form of dry $3 \mathrm{~kg}, 6 \mathrm{~kg}$ of tofu and $30 \mathrm{~kg}$ of forage every morning, with the same number is also given in the afternoon. Simental cow is a type of livestock, but ranchers maintain demplot as dairy cattle. At the beginning of the current demonstration milked cow milk production has been done simental only 2 liters. Urea red sugar block simental also given to cows, for 7 consecutive days with level 4 pieces of candy lick every day, after the start of production produced higher then 2 per day of administration used, the results achieved simental milk production to 13 liters a day and still survive with usage lick candy containing the leaf shapes. While dairy cow dairy cow is kind of milk production increased an average of 2 liters per day. Milk production is influenced by the feed consumed by the animal, if the feed is inadequate in terms of quality and quantity of the feed supplements provided will not mean anything. The increase in milk production of dairy cows is thought to originate from leaf meal wake red sugar urea contained in the block. Wake is known to increase feed intake, body weight gain, and efficient use of nutrients in pigs [6]. Furthermore [7], states that the leaf shapes have three essential components, the first component is the compounds that are lactagogue, ie components that can stimulate the production of milk glands in lactating mother. The second is a nutritional component and the third component is farmakoseutik ex. compounds that are buffers, antibacterial, antioxidants, lubricants, plasticizers, colorants and stabilizers [8].

The results of the study [5], obtained granting wake leaf meal in the ration of $3 \%$ parent suckling pig effective in increasing dry matter intake and protein, as well as improving the condition of the body weight. This result is also supported by the results of research [9], that the leaf meal supplementation wake can increase milk production by $67.22 \%-98.65 \%$. Milk production in dairy cattle influenced by genetic and environmental influences. As stated [10], Genetic influences on milk production has a heritability of $25 \%$. In other words, $75 \%$ of high and low milk production, determined by feeding and management factors. If feeding and management of dairy cattle are given in good, then milk production will be better. References [11], states that the quantity and quality of milk produced by an animal, is highly dependent on the various aspects involved in the process of lactation. Aspects include aspects of nutrition, 
physiology and biochemistry, which includes the nutrient content of food given, the process of nutrient metabolism, availability of precursors in the blood and milk synthesis mechanism.

\section{TABLE I}

EFFECT OF UREA SAKA BLOCK LEAF BUILD-WAKE ON MILK PRODUCTION

\begin{tabular}{|c|c|c|}
\hline Treatment & $\begin{array}{l}\text { Increased milk } \\
\text { production (liters) }\end{array}$ & $\begin{array}{l}\text { Percentage increase in milk } \\
\text { production (\%) }\end{array}$ \\
\hline $\mathrm{A}$ & 0.5 & 3 \\
$(2.5 \% \mathrm{WLM})$ & 2 & 10 \\
$\mathrm{~B}$ & & 6 \\
$(5 \% \mathrm{WLM})$ & 1.25 & \\
$\mathrm{C}(7.5 \% \mathrm{WLM})$ & \multicolumn{2}{|l}{} \\
\hline
\end{tabular}

The results of the study [5], obtained granting wake leaf meal in the ration of $3 \%$ parent suckling pig effective in increasing dry matter intake and protein, as well as improving the condition of the body weight. This result is also supported by the results of research [9], that the leaf meal supplementation wake can increase milk production by $67.22 \%-98.65 \%$. Milk production in dairy cattle influenced by genetic and environmental influences. As stated [10], Genetic influences on milk production has a heritability of $25 \%$. In other words, $75 \%$ of high and low milk production, determined by feeding and management factors. If feeding and management of dairy cattle are given in good, then milk production will be better. References [11], states that the quantity and quality of milk produced by an animal, is highly dependent on the various aspects involved in the process of lactation. Aspects include aspects of nutrition, physiology and biochemistry, which includes the nutrient content of food given, the process of nutrient metabolism, availability of precursors in the blood and milk synthesis mechanism.

Increased milk production of dairy cows in devotion is due to the effect of the active compounds in leaf shapes that carvacrol, which can increase the digestibility and energy production. Other active compounds is forskolin, which burns fat into energy. Thus, energy and other nutrients become more available to produce milk.

Figure 1 shows that the increase in milk production can be seen in the shapes of leaves giving $5 \%$ in urea saka block. The delivery techniques performed on dairy cows that are lactating in the first week for four consecutive days given 2 pieces USB USB in the morning and 2 afternoon, after only 2 pieces that were given in the morning and afternoon. This result is also supported from research [12], that the use of leaf shapes can increase milk production of lactating mother mice to $30 \%$. Reference [13], found that four hours after administration leaves wake action volume increased by 47.4\%. Reference [6], also reported that mothers who consume leaf shapes are in a fresh state, do not feel tired and healthier. On the maternal consumption of leaf shapes help control postpartum bleeding (bleeding after birth) and acts as a uterine cleansing agent (cleaning agents uterus). In nursing mothers, consume leaf shapes can increase milk production $65 \%$ and this is higher than the control group and the group of nursing mothers who consume fenugreek capsule (commercial products) that only $20 \%$ increase milk production.

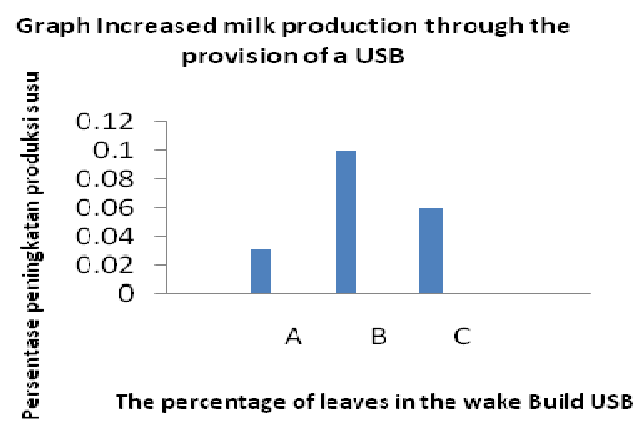

Fig. 1. Graphs the increase in milk production for science and technology activities

\section{CONCLUSIONS}

Community service activities which have been carried out in a herd of green valleys and valleys maknur prosperous one, in the village of Kampung Manggis, West Municipal District of Padang Panjang Of Padang Panjang, on the production of milk, it can be concluded as follows: (1) public knowledge about the management of a dairy farmer is good enough; (2) Application of technology of urea red sugar block leaf shapes can increase milk production by 2 liters per day perekor and increased milk production by about $10 \%$.

\section{REFERENCES}

[1] Badan Pusat Statistik Kota Padang Panjang.. Padang Panjang dalam Angka. 2012.

[2] A.Sudono, F. Rosdiana dan B. S. Setiawan. Intensive dairy cattle breeding Publisher. PT. AgroMedia Pustaka, Jakarta. 2004

[3] ND. Kaliappan, Viswanathan PK. Pharmacognostical studies on the leaves of Plectranthus amboinicus (Lour) spring. Int J Green Pharm.; Vol 2, issue 3:182-184.2008.

[4] E. Warsiki,., E. Damayanthy, R. Damanik. . Quality characteristics torbangun sop leaves (Coleus amboinicus L.) in cans and the calculation of the total migration of packaging materials . J Tek Ind Pert. ;Vol 18(3):21-24. 2009.

[5] S. Sinaga, dan A. Perdana. . Effect of wake flour (Coleus amboinicus L.) in pigs on feed conversion ration breastfeeding mother and child weight gain. Skripsi. 2010.

[6] R. Damanik. ., Damanik, M. L. Wahguist and Wattanapenpaibon. Lasctogogue effects bangun-bangun, a Bataknese tradiotional cuisine. APJCN; 15 (2) : 267 -274. 2006.

[7] Weaning, W. The addition of leaf shapes (Coleus amboinicus, Lour) in the ration effects on reproductive traits and milk production of white mice (Mus musculus Albinus. Thesis. Department of Animal Production. Faculty of Animal Husbandry. Bogor Agricultural University, Bogor. 2007.

[8] J. Khajarern. and S. Khajarern. The efficacy of origanum essential oils in sow feed. Int. Pig. Topics. P17. 2002.

[9] S.D. Rumetor, , J. Jachja., R. Widjajakusuma., I. G. Permana., dan I. K. Sutama. Supplementation wake leaves (Coleus amboinicus L) and Zinc-Vitamin E to improve metabolism and Peranakan Etawah goat milk production. Article. 2008.

[10] G. Haenleh. Feeding goats for improved milk and meat production. Departemen of Animal and Food Science University of Delaware. USA. 2002.

[11] R. M. Akers,. Lactation and the mamary gland. First Edition. Iowa State Press. Iowa. 2002.

[12] M. Silitonga, Effects laktagogum cumin leaves (Coleus amboinicus, L) lactation in rats. Graduate programs, Bogor Agricultural University.

[13] Ch.M Santosa,. Efficacy wake dau consumption (Coleus amboinicus, L) as facilitating the secretion of breast milk breastfeeding and baby petumbuhan spur. Thesis. Graduate Program, IPB Bogor. 2001 